IZA DP No. 5945

\title{
Cycles of Wage Discrimination
}

Jeff E. Biddle

Daniel S. Hamermesh

August 2011

Forschungsinstitut zur Zukunft der Arbeit Institute for the Study of Labor 


\title{
Cycles of Wage Discrimination
}

\author{
Jeff E. Biddle \\ Michigan State University \\ Daniel S. Hamermesh \\ University of Texas at Austin, \\ Maastricht University, NBER and IZA
}

\section{Discussion Paper No. 5945 \\ August 2011}

IZA
P.O. Box 7240
53072 Bonn
Germany

\author{
Phone: +49-228-3894-0 \\ Fax: +49-228-3894-180 \\ E-mail: iza@iza.org
}

\begin{abstract}
Any opinions expressed here are those of the author(s) and not those of IZA. Research published in this series may include views on policy, but the institute itself takes no institutional policy positions.

The Institute for the Study of Labor (IZA) in Bonn is a local and virtual international research center and a place of communication between science, politics and business. IZA is an independent nonprofit organization supported by Deutsche Post Foundation. The center is associated with the University of Bonn and offers a stimulating research environment through its international network, workshops and conferences, data service, project support, research visits and doctoral program. IZA engages in (i) original and internationally competitive research in all fields of labor economics, (ii) development of policy concepts, and (iii) dissemination of research results and concepts to the interested public.
\end{abstract}

IZA Discussion Papers often represent preliminary work and are circulated to encourage discussion. Citation of such a paper should account for its provisional character. A revised version may be available directly from the author. 


\section{ABSTRACT}

\section{Cycles of Wage Discrimination}

Using CPS data from 1979-2009 we examine how cyclical downturns and industry-specific demand shocks affect wage differentials between white non-Hispanic males and women, Hispanics and African-Americans. Women's and Hispanics' relative earnings are harmed by negative shocks, while the earnings disadvantage of African-Americans may drop with negative shocks. Negative shocks also appear to increase the earnings disadvantage of badlooking workers. A theory of job search suggests two opposite-signed mechanisms that affect these wage differentials. It suggests greater absolute effects among job-movers, which is verified using the longitudinal component of the CPS.

\section{NON-TECHNICAL SUMMARY}

This study considers how the disadvantages faced by women, minority groups and others change over the business cycle. Examining the U.S. from 1979-2009, it shows that women's and Hispanics' wages are relatively lower than white males' wages in bad times than in good times; but African-Americans do relatively better in bad times. The reason for the different responses to unemployment may be that there are two opposite effects on these measures of discrimination. Employers have a greater ability to indulge their desires to discriminate when unemployment is higher; but in bad times indulging those desires creates a greater risk of bankruptcy, because the employer's profit situation is more precarious. Examining differences between job-stayers and job-movers provides some support for this explanation.

JEL Classification: E29, J71

Keywords: $\quad$ women, minorities, beauty, search models

Corresponding author:

Daniel S. Hamermesh

Department of Economics

University of Texas

Austin, TX 78712

USA

E-mail: hamermes@eco.utexas.edu 


\section{Introduction and History}

For nearly 50 years the measurement of wage differentials between racial and ethnic groups, and between genders, has been a mainstay of empirical labor economics. Nearly all of the empirical work has implicitly been grounded in Becker's (1957) tastebased approach; and almost the entire oeuvre has either measured cross-section differentials or considered trends in these "discriminatory" differences. Relative to the attention paid to cross-section differences and trends in wage effects, remarkably little attention has been paid to how these differentials vary with the extent of labor-market tightness. The issue was mentioned only in passing in the first Handbook survey (Cain, 1986) and was not even alluded to in the sequel Handbook survey (Altonji and Blank, 1999).

A few studies from the 1970 s and 1980s did attempt to measure the cyclicality of discriminatory wage differentials (Ashenfelter, 1970; Freeman, 1973; O’Neill, 1985), analyzing aggregate time series of the ratio of annual earnings of disadvantaged compared to other workers. Measured cyclical movements in ratios of earnings per hour could arise from two distinct mechanisms: changes over the cycle in the characteristics of the workers in each group (composition effects) and changes over the cycle in pure wage discrimination. The authors recognized this and pointed to both mechanisms as reasons for expecting cyclicality in measured discriminatory wage gaps. Discussions of composition effects pointed to the greater "vulnerability" of women and minorities to cycle-related job loss, but also noted the tendency for women and minorities to be employed in more stable, albeit lower-wage, industries. Both O'Neill and Freeman concluded that composition effects led to a counter-cyclical movement in measured 
discriminatory wage differentials. Freeman and Ashenfelter offered reasons for suspecting that true wage discrimination would also be counter-cyclical, with Ashenfelter referring to an apparently common argument of the time that the perceived cost to employers of discriminating was higher in tight labor markets. But neither found empirical evidence of cyclical movements pure wage discrimination.

Since the mid-1990s, despite the continuing volatility of aggregate and local labor markets, including the recent turmoil caused by the Great Recession, almost no attention has been given to relationship between labor market tightness and discriminatory wage differentials. Numerous studies have used the CPS and other individual level data sets to study longer-term movements in discriminatory wage differentials, but this literature has been concerned with secular trends, with almost no mention made of the possible cyclicality of such differentials. ${ }^{1}$

In this study we remedy this neglect. In the next section we document the paths of wage differentials by gender (female/male), ethnicity (Hispanic/non-Hispanic) and race (black/white), using the Current Population Survey Merged Outgoing Rotation Groups (CPS-MORG) from 1979 through 2009. This is a sufficiently long period to cover four (or five, if one considers the early 1980s recessions as distinct) aggregate cycles. Since the CPS-MORG files provide individual level data with industry and geographic identifiers, we can measure more accurately the labor market environment facing each worker; and the longitudinal component of the CPS-MORG data allows us to go a long way toward distinguishing changes in measured wage differentials due to changes in pure wage discrimination from those due to composition effects.

\footnotetext{
${ }^{1}$ See, e.g., Blau and Kahn (2006), or Mulligan and Rubinstein (2008). Kuhn and Shen (2010) is a rare exception to this generalization, although in a very specific context.
} 
We find that the male-female wage gap is counter-cyclical, that is, the wage disadvantage faced by women grows when and where unemployment is temporarily higher. This does not appear to be due to a composition effect, but rather to changes in pure wage discrimination. The same is true of the wage disadvantage faced by Hispanics. The measured discriminatory gap for African- Americans, on the other hand, is procyclical, but this is partly the result of composition effects. In Section III we offer suggestive evidence of the counter-cyclicality of still another possibly discriminatory wage differential, one based on looks.

Section IV sets out a search-theoretic model of discrimination to aid in interpreting the evidence. We show that a standard random search model with employer discrimination implies a cost to employers of indulging discriminatory tastes that varies pro-cyclically, thus providing a formal version of the argument cited by Ashenfelter and others; but the model also points to other ways that discriminatory wage differentials might be affected by a changing unemployment to vacancy ratio. The implication of this model that economic fluctuations will change discriminatory wage differentials through their impact on the wage changes experienced by job-changers is supported in the data.

\section{Data and Evidence-Current Population Survey, 1979-2009}

\section{A. Basic Estimates}

Throughout this section we use the Current Population Survey Merged Outgoing Rotation Groups beginning 1979, the first year for which they are available. We proxy wages by reported usual weekly earnings, but we adjust weekly earnings by including a quadratic in usual weekly hours among the independent variables. We create indicator 
variables $\mathrm{M}$ for female, Hispanic or African-American. ${ }^{2}$ In addition, throughout we adjust wages by holding constant for a wide range of CPS covariates, X, including a vector of indicators of educational attainment, a quadratic in potential experience, and indicators of marital status, metropolitan location, veteran status and private/public sector employment. The samples are restricted to wage and salary workers- the self-employed are excluded, as are members of the armed forces.

For each year we calculate the unemployment rate $\mathrm{U}$ in each state and use that as the cyclical indicator. We thus estimate:

$$
\mathrm{W}_{\text {ist }}=\alpha_{1} \mathrm{M}_{\text {ist }}+\alpha_{2} \mathrm{U}_{\text {st }}+\alpha_{3} \mathrm{M}_{\text {ist }} \mathrm{U}_{\text {st }}+\beta \mathrm{X}_{\text {ist }}+v_{\mathrm{s}}+\tau_{\mathrm{t}}+\varepsilon_{\text {ist }},
$$

where i denotes an individual, s a state and $\mathrm{t}$ a year, and $\mathrm{W}$ is the logarithm of weekly earnings. The $v_{\mathrm{s}}$ and $\tau_{\mathrm{t}}$ are state and year fixed effects respectively. While we initially estimate (1) without either of these vectors, and then include only the state fixed effects or only the year fixed effects, to save space the tables shown below report results from regressions that include both vectors. Separate equations are estimated with $\mathrm{M}$ representing females, Hispanics and African-Americans, so that the estimate of $\alpha_{1}+\alpha_{3} U$ denotes the wage differential relative to all other workers. The coefficients on $\mathrm{U}$ listed in the Table treat unemployment as a fraction of the labor force.

When we estimate (1) with the vector of state fixed effects we are implicitly focusing on temporary variations in the tightness of state labor markets. This specification accounts for the possibility that in certain states unemployment may be above or below the national average in most or all years (although Marston, 1985, suggests not). Such long-term differences are arguably related to wage differences (e.g.,

\footnotetext{
${ }^{2}$ For the later years, when the CPS offers a large variety of racial characteristics, we code as AfricanAmerican only those who listed that as their sole racial identification.
} 
Hall, 1970, but going back to Smith, 1776) and may also be correlated, coincidentally or not, with interstate differences in general attitudes towards various minorities. When we estimate (1) including the vector of year fixed effects, we are implicitly abstracting from aggregate cycles. Adding both state and year fixed effects to the regression reduces the precision in our estimates of the impact of changes in unemployment on discriminatory wage differentials, but alleviates any bias caused by a correlation between secular changes in the natural rate of unemployment and secular changes in attitudes towards women and minorities.

Table 1 contains the main results of the estimated equations that include the "minority" indicators. For the race/ethnicity categories we present the parameter estimates for the indicator in an equation estimated over the entire sample, and then separately for males and females in each case. We show only the main effect of the indicator, the main effect of the state unemployment rate, and their interactions - the parameters $\alpha_{j}$-as the estimates of the $\beta$ are standard. ${ }^{3}$

Consider first the results for women. With a mean state unemployment rate of 0.0601 over this period, the wage disadvantage of women, other things equal, averages about 11 percent. The interaction term is significantly negative - as the unemployment rate increases the wage disadvantage facing women increases. This effect does not depend on our inclusion of the state and year fixed effects: The interaction term is negative and statistically significant even without either one or both of these. Clearly, measured discrimination against females generally is counter-cyclical.

\footnotetext{
${ }^{3}$ Throughout the estimates are based on equations with observations weighted by the CPS sampling weights.
} 
Considering next the results in Columns (2)-(4) for Hispanics, we see that generally the wage disadvantage is around 16 percent, greater for Hispanic males, less for female Hispanics. The pattern of the Hispanic wage disadvantage is weakly countercyclical, because it is composed of a significantly counter-cyclical effect among Hispanic men, and a statistically insignificant pro-cyclical effect among Hispanic women. Unlike women generally, these effects do depend upon whether the vectors of state and year fixed effects are included in the estimates. When these are excluded the interaction terms for Hispanics generally, and for Hispanic women, are positive and statistically significant, with most of the change resulting from the exclusion of the state fixed effects. Because of the concentration of Hispanics in a few, high-unemployment states, we believe that excluding the vector of state indicators is incorrect.

The final three columns of Table 1 present the results for all African-Americans and for African-American men and women separately. The wage disadvantage overall averages about 10 percent, somewhat more among men. More important, the interaction terms are positive and statistically significant for the whole sample and among men and women separately. The results among African-American women are unchanged whether we include the vector of state fixed effects, the vector of year fixed effects, or neither. If these vectors are excluded, however, the interactions for the entire sample, and the sample of men only, remain positive but lose their statistical significance.

The impacts of a typical recession vary sharply across the gender/race/ethnic groups, with the biggest effect among women. For them an increase of 4.7 percentagepoints in average unemployment (which occurred in the Great Recession) increases their wage disadvantage by nearly 5 percentage points; among Hispanics the effect is tiny —an 
increase in their wage disadvantage of less than 1 percentage point, while among AfricanAmericans this severe a recession reduces their wage disadvantage by about 1.5 percentage points.

\section{B. Extensions}

The samples include many workers who may be insulated from cyclical shocks. The wages of junior and less educated workers may be more responsive to changes in labor-market conditions than those of their seniors and of workers with greater educational attainment. ${ }^{4}$ Since wages of these workers are more responsive, perhaps the responsiveness of the discriminatory wage differentials among them, those more likely to be newly hired or to face a seniority-based layoff, is greater too. To examine this possibility we restrict the samples to workers who have not completed a college education and who have five or fewer years of potential labor-market experience. The results of the estimates based on these restricted samples are presented in Table 2 in the same format as in Table 1.

The results for women in Table 2 are qualitatively identical to those in Table 1. For this restricted sample of younger and less educated women, the female wage disadvantage increases with rises in unemployment. ${ }^{5}$ The estimates of the interaction terms among Hispanics do, however, change compared to those for the entire sample, becoming more positive (a smaller wage disadvantage with rising unemployment). Indeed, for this inexperienced group of workers there is no evidence of any statistically significant cyclical variation in the wage disadvantage of Hispanics. Among African-

\footnotetext{
${ }^{4}$ For an insightful early discussion, see Reder (1955).

${ }^{5}$ The result is unchanged when we delete the vector of state fixed effects, the vector of year fixed effects, or both.
} 
Americans the wage disadvantage in this restricted sample varies more negatively with rising unemployment than in the entire sample, so that there is essentially no cyclicality in it. The absence of any cyclical variation among African-Americans generally is comprised of a statistically insignificant negative relationship among men, and a significant positive relationship among women.

The results thus far have been based on samples covering thirty-one years. Given the documented changes in the labor markets for members of all three "minorities," perhaps the extent of cyclical variation in their wages over this period changed too. To examine this possibility we first divide the entire sample period into two parts, 1980-92 and 1993-2009 (each thus comprising two aggregate business cycles) and re-estimate the equations over the entire sample and the samples of men and women.

The estimates over these two sub-periods are shown in Table 3. Among women the results in the earlier sub-period are the same as before-apparently increasing discrimination as unemployment increases; but in the later sub-period the results reverse, with apparent discrimination falling as unemployment increases. Among Hispanics the estimates are consistent with those in Table 1, and perhaps even stronger, showing that for the entire group and among men and women separately, the wage disadvantage increases as unemployment increases. Lastly, among African-Americans the estimates suggest a roughly similar conclusion as those for the entire sample - that the wage disadvantage declines when the unemployment rate rises.

The cyclicality of wage differentials measured in the regressions reported thus far could arise from both cyclicality in pure wage discrimination and from unemploymentrelated changes in the unobservable characteristics of the sample of employed workers- 
a composition effect in the unobservables. The short longitudinal structure of the CPSMORG, in which many households are interviewed twice at a one-year interval, allows us to examine the co-movement of unemployment rates and discriminatory wage differentials in a group of workers of constant composition, thus eliminating even these composition effects. This analysis thus controls for possible interactions between a wide range of unobservable individual characteristics with the unemployment rate.

Table 4 presents the results of regressions in which the sample is restricted to observations that had positive earnings in both months 4 and 8 (one year apart) of their participation in the CPS and which include person fixed effects, so that state fixed effects are implicit in the estimation. ${ }^{6}$ We present estimates for the entire sample period and then separately for the two sub-periods. Essentially we difference (1) so that the dependent variable is the change in log-earnings, and the only independent variables are $M$, the change in the state unemployment rate, their interaction, and linear terms in experience and current and year-lagged weekly hours.

The results for women are unambiguous - for the whole sample and the two subperiods the wage disadvantage of women grows when and where unemployment is temporarily higher, just as it did in the cross sections. Thus, the positive relationship between the unemployment rate and the wage disadvantage faced by women would seem to be the result of cyclical movements in pure wage discrimination. Table 4 even shows that the apparent reversal of sign of the relationship between unemployment and the male-female wage gap during the latter half of our sample period was due to a change in the impact of unobservable, unemployment-related composition effects on the measured

\footnotetext{
${ }^{6}$ This arises because of the household basis of the CPS.
} 
gap rather than a change in the cyclicality of wage discrimination. This observation would seem to be consistent with Mulligan and Rubinstein's (2008) finding that the nature of selection into the female labor force changed between the 1970s and the 1990s.

The estimates also show that the relatively weak positive relationship between unemployment and the wage disadvantage facing Hispanics in the cross-section becomes considerably stronger when composition effects arising from unobservables are removed. Hispanic workers who keep their jobs as unemployment rises implicitly have increasingly more desirable unobservable characteristics than do non-Hispanic workers who keep their jobs. The positive co-movement of the relative wages of African-Americans and unemployment that we saw in Table 1 diminishes in magnitude and becomes insignificant when measured in this sample with unchanging unobservable composition.

While we have carefully accounted for labor-market-wide effects, treating states as labor markets, we have ignored the job-specific impacts of changes in demand. The question is whether, given the state's labor market, the impact of job-specific shocks mirrors that of a labor-market-wide shock. To examine this we respecify (1) as:

$$
\begin{aligned}
& \mathrm{W}_{\text {ist }}=\alpha_{1} \mathrm{M}_{\text {ist }}+\alpha_{2} \mathrm{U}_{\text {st }}+\alpha_{3} \mathrm{M}_{\text {ist }} \mathrm{U}_{\text {st }}+\alpha_{4} \Delta \mathrm{H}_{\text {it }}+\alpha_{5} \Delta \mathrm{H}_{\mathrm{it}} \mathrm{M}_{\text {ist }}+\alpha_{6} \Delta \mathrm{H}_{\mathrm{it}} \mathrm{U}_{\text {st }}+ \\
& +\alpha_{7} \Delta \mathrm{H}_{\mathrm{it}} \mathrm{M}_{\mathrm{ist}} \mathrm{U}_{\text {st }}+\beta \mathrm{X}_{\text {ist }}++v_{\mathrm{s}}+\tau_{\mathrm{t}}+\varepsilon_{\text {ist }},
\end{aligned}
$$

where $\Delta \mathrm{H}_{\mathrm{it}}$ is the percentage change in total person-hours worked in the CPS industry between years $\mathrm{t}-1$ and $\mathrm{t}$.

We present estimates of the $\alpha_{\mathrm{j}}$ in (2) in Table 5 for equations with the seven specifications of the indicator M. As before, unemployment is treated as fractional, as is $\Delta \mathrm{H}_{\mathrm{it}}$. The estimates are trimmed to remove industry/year observations in which the calculations from the CPS implied an absolute annual change in total person-hours 
exceeding 50 percent. This amounts to deleting 2.3 percent of the industry-year observations, but only 0.1 percent of the individuals in the 1980-2009 samples (as the extreme fluctuations in industry person-hours are due to small sample sizes in the particular industries). ${ }^{7}$

First, although not shown in the table, the estimates of $\partial^{2} \mathrm{~W} / \partial \mathrm{M} \partial \mathrm{U}$ at the average $\Delta \mathrm{H}$ differ only very slightly from the estimates in Table 1 (not surprisingly, given the lack of correlation between state unemployment rates and annual changes in economywide industry hours worked). Thus accounting for industry-specific changes in employment does not alter the conclusion that the female and Hispanic wage disadvantages rise as unemployment rises, and the African-American wage disadvantage falls.

To answer whether industry-specific shocks affect gender/racial/ethnic wage differentials in the same way as market-wide shocks, we focus on the estimates of $\partial^{2} \mathrm{~W} / \partial \mathrm{M} \partial \Delta \mathrm{H}$ at the average $\mathrm{U}$, shown at the bottom of Table 5. In most cases the sign of this estimate is opposite that of the interaction term shown in Table 1. Thus among women we observe the same negative effect on wage differentials of declines in industry demand that we observed for cyclical labor-market rises in unemployment in Table 1—as $\Delta \mathrm{H}$ is more negative, women's wages fall relative to men's. Among African-Americans the same positive effect is observed-as $\Delta \mathrm{H}$ drops, African-Americans' wages rise relatively. The opposite is true for Hispanics: Unusually large drops in industry demand decrease the relative wages of Hispanics, just as did cyclical increases in unemployment. A fair conclusion is that the effects of industry-specific are the same as those of cyclical, market-wide shocks.

\footnotetext{
${ }^{7} \mathrm{We}$ spliced the series using the overlapping industry definitions in the 2002 CPS.
} 


\section{Another "Discriminatory" Dimension-Looks}

There is by now a wide array of studies demonstrating that, other things equal, worse-looking workers of both sexes earn less than their better-looking peers, both generally and within a wide array of occupations (summarized in Hamermesh, 2011, Chapters 3 and 4). As another illustration of the cyclical variation in "discriminatory" wage differences, we can combine evidence from two studies of the earnings of attorneys to examine cyclicality in the pay penalty for bad looks. In Biddle and Hamermesh (1998) we examined twelve cohorts of graduates from a prestigious law school whose earnings were observed one year, five years and fifteen years post-graduation. The estimated effects of a one-standard deviation improvement in attorneys' looks are reproduced in Table 6. The cohorts of attorneys who entered the labor market for lawyers between 1972 and 1977 faced a growing and significant beauty premium (and ugliness penalty) as their careers progressed. The earnings of attorneys in the cohorts that graduated between 1982 and 1987 were unaffected by differences in their looks, at least early in their careers.

Figure 1 reproduces Rosen's (1992) graphical description of lifetime earnings forecasts facing entrants into this labor market at each year of graduation, 1967-1987. We can compare the earnings that could have been expected by those attorneys who graduated in the early to mid-1970s to those who graduated in the early to mid-1980s. Clearly, real and relative earnings were higher in the latter period; and Rosen (1992) demonstrates that this difference arose from the tighter labor market for attorneys. Comparing these findings to the results in Table 6 suggests that the impact of looks on earnings - and the "discriminatory" disadvantage in pay of bad-looking workers —was 
smaller in the tighter legal labor market of the 1980s than in the looser legal market of the 1970s. The findings for this occupational labor market are similar to those for female and Hispanic workers, but opposite that for African-American workers.

\section{Modeling Discrimination over the Cycle}

The previous sections have presented compelling evidence that discriminatory wage gaps are related to labor market tightness, a relationship that shows up even in analyses of co-movements of wage and unemployment over a year in samples of unchanging composition. In this section we outline an equilibrium search model intended to provide some insights into why pure wage discrimination might be related to labor market tightness, a model that builds on the work of Black (1995) and Rosén (2003). It contains two types of workers, one of which is subject to employer discrimination in the labor market. The model explores the intuition that the rising ratio of job seekers to vacancies during a recession might give employers more scope to indulge discriminatory tastes, while bringing to light other ways that cyclical fluctuations affect discriminatory wage differentials. We present enough of the model to make clear the key mechanisms; an appendix available from the authors contains a complete characterization of the equilibrium.

There are two types of worker, type A and type B. Type A workers are favored and account for a fraction $\lambda$ of job seekers. Workers search randomly across vacancies offered by employers. Each potential vacancy is associated with a value of the discrimination coefficient $\mathrm{c}$, which is distributed across vacancies over a range from zero to $c_{\max }$. A vacancy's discrimination coefficient manifests itself as a tax on the employer 
who hires a type B worker into the vacancy, but it may influence the wage paid to a type A worker hired into that vacancy.

Equations (2) and (3) express the value to a worker of type i of being unemployed $\left(\mathrm{U}_{\mathrm{i}}\right)$ versus being employed in a position with discrimination coefficient $\mathrm{c}\left(\mathrm{W}_{\mathrm{i}}(\mathrm{c})\right)$.

$r U_{i}=\theta z_{i}\left[E\left(W_{i}(c)\right)-U_{i}\right], i=A, B$

$\mathrm{rW}_{\mathrm{i}}(\mathrm{c})=\mathrm{w}_{\mathrm{i}}(\mathrm{c})+\mathrm{s}\left[\mathrm{U}_{\mathrm{i}}-\mathrm{W}_{\mathrm{i}}(\mathrm{c})\right]$

In (3) $r$ is the discount rate, $\theta$ is the rate at which workers receive job offers, $z_{i}$ is the probability that the employer will be willing to hire the worker of type $\mathrm{i}$, and $\mathrm{E}\left(\mathrm{W}_{\mathrm{i}}(\mathrm{c})\right)$ is the expected value, for worker type $i$, of being employed, where the expectation is taken over the distribution of $\mathrm{c}$. In (4) $\mathrm{s}$ is an exogenous separation rate, and $\mathrm{w}_{\mathrm{i}}(\mathrm{c})$ the wage earned by a type i worker at a job with a discrimination coefficient of $\mathrm{c}$.

Equations (5) and (6) give the value to the employer of a vacancy and a filled job as functions of the job's discrimination coefficient, c.

$\mathrm{rV}(\mathrm{c})=-\mathrm{k}+\varphi \mathrm{y}(\mathrm{c})\left[\mathrm{E}\left(\mathrm{J}_{\mathrm{i}}(\mathrm{c})-\mathrm{V}(\mathrm{c})\right]\right.$

$\mathrm{rJ}_{\mathrm{i}}(\mathrm{c})=\mathrm{x}-\mathrm{w}_{\mathrm{i}}(\mathrm{c})-\mathrm{c}_{\mathrm{i}}+\mathrm{s}\left[\mathrm{rV}(\mathrm{c})-\mathrm{J}_{\mathrm{i}}(\mathrm{c})\right], \mathrm{i}=\mathrm{A}, \mathrm{B}$

In (5) $\mathrm{k}$ is the cost of keeping a vacancy open for a period, $\varphi$ is the rate at which workers arrive at employers, and $y(c)$ is the probability that the randomly arriving worker will be acceptable to the employer, which depends on the vacancy's c value. The expectation in (5) is taken over the distribution of worker types. In (6) $\mathrm{x}$ is the value of a worker's product, assumed the same for all workers in all jobs, and $\mathrm{c}_{\mathrm{i}}$ is equal to zero if a type A worker is hired, and equal to the vacancy's discrimination coefficient if a type B worker is hired.

Because it costs to keep a vacancy open, and there is a foregone surplus from a filled job, the employer offering a vacancy with a non-zero c faces a tradeoff. Hiring a 
type B worker has a psychic cost, c, which for some vacancies will be greater than the equilibrium wage discount for type B workers; but turning the worker away and waiting for a type A worker to apply generates a cost in terms of $\mathrm{k}$ and forgone $\mathrm{x}$ that is proportional to the waiting time.

Following common practice, we assume that, when a worker meets an employer in the search process, the wage is determined by a Nash bargaining process, which gives the worker a share $\beta$ of the surplus. The potential surplus for an i worker and a $\mathrm{c}$ vacancy is $\left(\mathrm{W}_{\mathrm{i}}(\mathrm{c})-\mathrm{U}_{\mathrm{i}}\right)+\left(\mathrm{J}_{\mathrm{i}}(\mathrm{c})-\mathrm{V}(\mathrm{c})\right)$. Replacing $\mathrm{W}_{\mathrm{i}}(\mathrm{c})$ and $\mathrm{J}_{\mathrm{i}}(\mathrm{c})$ in this expression with (4) and (6) yields a wage equation for a type-i worker in a c vacancy:

$\mathrm{w}_{\mathrm{i}}(\mathrm{c})=\beta\left(\mathrm{x}-\mathrm{c}_{\mathrm{i}}-\mathrm{rV}(\mathrm{c})\right)+(1-\beta) \mathrm{rU}_{\mathrm{i}}$

Equations (5)-(7) can be used to derive two possible values for a c-vacancy. Let $\mathrm{V}^{\mathrm{AB}}$ represent the value of the vacancy if the employer is willing to fill it with either type of worker, and $\mathrm{V}^{\mathrm{A}}$ stand for the value of the vacancy if the employer hires only A type workers. Then:

$$
\begin{aligned}
& \mathrm{rV}^{\mathrm{AB}}(\mathrm{c})=\left\{-\mathrm{k}(\mathrm{r}+\mathrm{s})+(1-\beta) \varphi\left[\mathrm{x}-(1-\lambda) \mathrm{c}-\lambda \mathrm{rU}_{\mathrm{A}}-(1-\lambda) \mathrm{rU}_{\mathrm{B}}\right]\right\} /(\mathrm{r}+\mathrm{s}+(1-\beta) \varphi) \\
& \mathrm{rV}^{\mathrm{A}}(\mathrm{c})=\left\{-\mathrm{k}(\mathrm{r}+\mathrm{s})+(1-\beta) \varphi \lambda\left[\mathrm{x}-\mathrm{rU}_{\mathrm{A}}\right]\right\} /(\mathrm{r}+\mathrm{s}+(1-\beta) \varphi \lambda) .
\end{aligned}
$$

Whether a vacancy is segregated or integrated depends on which of these values is higher, and that depends on the value of c. Setting (8a) equal to (8b) gives a cutoff value $\mathrm{c}^{*}$, such that vacancies for which $\mathrm{c}>\mathrm{c}^{*}$ will be filled only with A workers:

$\mathrm{c}^{*}=\left\{\left[(\mathrm{r}+\mathrm{s})(\mathrm{k}+\mathrm{x})+(1-\beta) \varphi \lambda \mathrm{rU}_{\mathrm{A}}\right] /[\mathrm{r}+\mathrm{s}+(1-\beta) \varphi \lambda]\right\}-\mathrm{rU}_{\mathrm{B}}$

A higher $\mathrm{c}^{*}$ means less discrimination. A higher cost of waiting $(\mathrm{k})$ or a higher value of production (x) leads to less discrimination, since the cost of discriminating is waiting for the next worker to come along if a B worker is denied the job. 
Let $\mathrm{H}\left(\mathrm{c}^{*}\right)$ be the probability that $\mathrm{c}<\mathrm{c}^{*}$, so that $\mathrm{Z}_{\mathrm{B}}$, the probability that a vacancy found by a type B worker will be filled by him, is $\mathrm{H}\left(\mathrm{c}^{*}\right)$, while $\mathrm{z}_{\mathrm{A}}=1$. Then (3) and (4) and the wage equation (7) yield expressions for the value of search for each type of worker:

$\mathrm{rU}_{\mathrm{A}}=[\theta \beta \mathrm{E}(\mathrm{x}-\mathrm{rV}(\mathrm{c}))] /(\mathrm{r}+\mathrm{s}+\theta \beta)$

$\mathrm{rU}_{\mathrm{B}}=\left[\theta \beta \mathrm{E}\left(\mathrm{x}-\mathrm{c}-\mathrm{rV}(\mathrm{c}) \mid \mathrm{c}<\mathrm{c}^{*}\right) \mathrm{H}\left(\mathrm{c}^{*}\right)\right] /\left(\mathrm{r}+\mathrm{s}+\theta \beta \mathrm{H}\left(\mathrm{c}^{*}\right)\right)$,

where the expectations are over the distribution of $\mathrm{c}$. These equations can be used to show that $U_{A}>U_{B}$, which, given the wage equation (7), implies that in equilibrium the $B$ worker receives a lower wage than the A worker at any employer willing to hire both types. ${ }^{8}$ Also, as $\mathrm{V}^{\mathrm{AB}}$ is declining in $\mathrm{c}$, wages for both $\mathrm{A}$ and $\mathrm{B}$ workers fall as $\mathrm{c}$ increases up to $\mathrm{c}^{*}$, at which point there is no wage for B workers and the A wage remains constant.

The arrival rate of workers $\varphi$, which is one factor determining the cost to employers of discrimination, depends on the processes governing the number of searching workers and the number of vacancies offered. Letting the total number of workers equal 1, a fraction $\alpha$ of whom are type $\mathrm{A}$, and letting the number unemployed for type $\mathrm{A}$ and type $\mathrm{B}$ workers be $\mathrm{u}_{\mathrm{A}}$ and $\mathrm{u}_{\mathrm{B}}$, the change over time in the number unemployed can be written as $\mathrm{du}_{\mathrm{A}}=\mathrm{s}\left(\alpha-\mathrm{u}_{\mathrm{A}}\right)-\theta \mathrm{u}_{\mathrm{A}}$ and $\mathrm{du}_{\mathrm{B}}=\mathrm{s}\left((1-\alpha)-\mathrm{u}_{\mathrm{B}}\right)-\theta \mathrm{H}\left(\mathrm{c}^{*}\right) \mathrm{u}_{\mathrm{B}}$. In a steady state unemployment is constant, so that the steady-state rates of unemployment are given by:

$$
\begin{aligned}
& \mathrm{u}_{\mathrm{A}}=\alpha \mathrm{s} /(\mathrm{s}+\theta) \\
& \mathrm{u}_{\mathrm{B}}=(1-\alpha) \mathrm{s} /\left(\mathrm{s}+\theta \mathrm{H}\left(\mathrm{c}^{*}\right)\right) .
\end{aligned}
$$

\footnotetext{
${ }^{8}$ As in Black (1995) and Rosén (2003), the value of search (U) is lower in equilibrium among type B workers, because they have a longer expected search time before finding a vacancy that will fill. This weakens their bargaining position when they do find an employer, so they end up with a lower wage.
} 
Group-specific unemployment rates can be found by dividing (11a) and (11b) by $\alpha$ and (1 $-\alpha$ ), respectively, leading to the unsurprising result that the unemployment rate for B type workers will always be higher than the unemployment rate for A type workers. Also, $\lambda$, the share of unemployed workers who are Type A, will always be lower than $\alpha$, the share of type A workers in the economy.

To endogenize the number of vacancies, assume that there are $M$ potential vacancies that will become actual vacancies if their value is greater than zero. In order to have an equilibrium in which discriminators can survive long-run entry, we follow Black (1995) by assuming differences in entrepreneurial ability that are attached to potential employers. Entrepreneurial ability is represented by a fixed cost that is incurred if a vacancy is opened (and persists whether it is filled or not). We represent this cost by the parameter $\varepsilon$, assumed to be distributed uniformly across vacancies on the interval 0 to $R_{\varepsilon}$, independent of the discrimination coefficient $\mathrm{c}$, which is also assumed to be distributed uniformly across potential vacancies. The fixed cost parameter appears as a term subtracted from the value equations (7a) and (7b).

Potential vacancies will become actual vacancies if:

$\varepsilon_{\mathrm{j}}<\mathrm{rV}^{\mathrm{AB}}\left(\mathrm{c}_{\mathrm{j}}, \mathrm{c}^{*}\right)$ if $\mathrm{c}_{\mathrm{j}}<\mathrm{c}^{*}$

$\varepsilon_{\mathrm{j}}<\mathrm{rV}^{\mathrm{A}}\left(\mathrm{c}^{*}\right) \quad$ if $\mathrm{c}_{\mathrm{j}}>\mathrm{c}^{*}$,

where $\mathrm{j}$ indexes vacancies, each of which has an $\varepsilon$ value and a c value. The value of vacancy equations are function of $c^{*}$ because the value of search $U_{i}$, which affects the value of a vacancy, is a function of $c^{*}$. The value of a vacancy is a direct function of $c$ only for employers who integrate. This means that in equilibrium, the number of vacancies will be: 


$$
\mathrm{v}=\mathrm{M} /\left(\mathrm{c}_{\max } \mathrm{R}_{\varepsilon}\right)\left\{\int_{0}^{\mathrm{c}^{*}} \mathrm{rV}^{\mathrm{AB}}\left(\mathrm{c}, \mathrm{c}^{*}\right) \mathrm{dc}+\left(\mathrm{c}_{\max }-\mathrm{c}\right) \mathrm{rV}^{\mathrm{A}}(\mathrm{c})\right\}
$$

With equations for the number of vacancies and the number of unemployed workers we can characterize the arrival rates $\theta$ and $\varphi$. As is common in the literature, we assume a matching function $\mathrm{m}\left(\mathrm{u}_{\mathrm{A}}+\mathrm{u}_{\mathrm{B}}, \mathrm{v}\right)$ that describes the number of meetings between searching workers and vacancies that will occur in a period. The number is increasing in both vacancies and (because search is random) the total number unemployed. Adding the conventional assumption that the matching function exhibits constant returns to scale allows the rate at which a searching worker meets a vacancy to be written as:

$\theta=m\left(u_{A}+u_{B}, v\right) /\left(u_{A}+u_{B}\right)=m\left(1, v /\left(u_{A}+u_{B}\right)\right)$,

while the rate at which employers see workers showing up at vacancies is:

$\varphi=m\left(u_{A}+u_{B}, v\right) / v=m\left(\left(u_{A}+u_{B}\right) / v, 1\right) \quad$.

In the context of this model, we represent macroeconomic fluctuations as changes in the value of $x$, the value to the firm of a workers' output. It is possible to differentiate the equilibrium value of the wage gap with respect to changes in $\mathrm{x}$, but this leads to a complex and non-transparent expression with an ambiguous sign. The model can, however, be used to think through the step-by-step impact of a recession on employers, workers, and market-level variables, thus providing some insight into the sources of this ambiguity and their possible correspondence to real world phenomena.

As discussed above, one cost to discriminating is the opportunity cost of the longer expected wait until an acceptable worker arrives, and this cost falls with a fall in the value of output. Employers who might not discriminate when the value of output is 
high will do so when it is low. Thus the model captures the idea that discrimination will be more costly in a tighter labor market. A greater proportion of discriminating employers in the labor market lowers the bargaining power of type B workers relative to type A workers, increasing the wage gap.

Another immediate impact of a drop in $\mathrm{x}$, however, serves to increase the bargaining power of type B workers. Other things equal, the fall in the value of workers' product lowers the perceived value of both filled jobs and vacancies, causing some vacancies and jobs to be eliminated. But the model suggests that jobs and vacancies that are closed to type B workers are more likely to disappear. The existence of differing entrepreneurial ability means that there are marginal positions at every level of c, and these are the positions (filled or vacant) that disappear when a recession lowers $\mathrm{x}$. There are, however, more infra-marginal positions at lower values of $\mathrm{c}$. Therefore when $\mathrm{x}$ falls the proportion of positions that disappears is greater at higher values of $\mathrm{c}$. This tends to lower the share of type-A only vacancies, raising the value of search for type B workers, and thus raising their bargaining power and wages relative to those of A workers.

Figure 2 depicts the nature of the equilibrium and illustrates the two initial and countervailing effects of a recession. On the axes are $\varepsilon$ and $\mathrm{c}$, so that potential vacancies are distributed uniformly over the quadrant. The line labeled $\mathrm{V}(\mathrm{c})=0$ shows the dividing line between combinations of $\mathrm{c}$ and $\varepsilon$ for which vacancies have positive utility (below the line) and those for which they have negative utility. Positive utility vacancies with $\mathrm{c}>\mathrm{c}$ * hire only majority (A) workers; because $\mathrm{V}(\mathrm{c})$ declines in $\mathrm{c}$ up to $\mathrm{c}^{*}$, some $\mathrm{AB}$ (integrated) vacancies yield a higher surplus than any segregated vacancy. The first impact of a recession is to lower the value of a vacancy (the shift from $V(c)$ to $V(c)$ ' in the figure) in 
a way that lowers the level of $\mathrm{c}^{*}$, decreasing the share of positions potentially open to type B workers, and increasing the wage gap. However, as the figure also shows, the proportion of segregated positions that disappears is larger than the proportion of integrated positions that disappear, as a consequences of the fact that there are more infra-marginal positions at values of $\mathrm{c}$ below $\mathrm{c}^{*}$.

As positions disappear, the rate at which workers arrive at employers rises, but the rate at which workers find new vacancies drops. As noted above, the higher arrival rate of workers at vacancies lowers the cost of discriminating, because a faster arrival of the next worker means less foregone output when a type B worker is turned away. This lowers the cutoff value of $\mathrm{c}^{*}$, which in turn lowers the value of search for type B workers relative to type A workers. A similar effect results from disproportionately more type A than type B workers losing jobs, raising the share of type A workers among the searchers and lowering the expected waiting time for the next type A applicant for firms who turn away type B workers. The lower arrival rate of job offers to workers lowers the value of search for both type A and type B workers, which lowers the wage of both types; but it lowers the value of search more for type A workers. This decreases the wage gap, but is a rather subtle, non-intuitive effect, as are the impacts of the many of the subsequent equilibrating reactions of the model's variables to the initial events set in motion by a fall in $\mathrm{x}$.

Although our model leaves open the question of whether discriminatory wage differentials are pro-cyclical or counter-cyclical, it does identify several distinct mechanisms through which business-cycle fluctuations could plausibly alter discriminatory wage differentials. These include cycle-induced changes in the costs and benefits of discrimination in hiring and changes in the mix of discriminators vs. non- 
discriminators in the labor market caused by entry or exit. In addition, our argument about the process by which cyclical fluctuations in the value of output move wages towards new equilibrium values suggests that changes in discriminatory wage differentials associated with aggregate fluctuations will be due to the impact of these fluctuations on changes in the relative wages received by advantaged vs. disadvantaged workers who leave one job and search for another, as opposed to their impact on wages paid to workers continuing in the same job. Indeed, there is no mechanism in the model through which wages change for workers who do not change employers.

\section{Job-Movers vs. Job Stayers}

The short longitudinal structure of the CPS allows us to compare cyclical changes in gender/racial/ethnic wage differentials between job-movers and job-stayers, thus providing a test of the model's implication that changes in unemployment affect wage gaps through their impact on the wage changes experienced by job changers. The CPS does not identify employers, so we assume that workers who list the same small industry of employment in interviews in years $\mathrm{t}-1$ and $\mathrm{t}$ are job-stayers, while those who list different industries are job-movers. Given evidence of substantial reporting error in the self-classification of industry affiliation (Freeman, 1984), our test will thus underestimate the differences in effects between job-stayers and job-movers, since some job-stayers are mistakenly classified as job-movers. Finally, with losses of perhaps $1 / 3$ of the CPS observations due to an inability to match across the pair of years, and other observations dropped because individuals enter or leave employment, the sample sizes here are smaller than those used in the cross-section analyses in Section III, but, of course, the same as in the analyses reflected in Table 4. 
To save space, in Table 7 we present only estimates of the interaction terms $\partial 2 \Delta \mathrm{W} / \partial \mathrm{M} \partial \mathrm{U}$ and their standard errors from the equations for job-stayers and -movers, along with what is essentially the triple difference $\left[\partial^{2} \Delta \mathrm{W} / \partial \mathrm{M} \partial \mathrm{U}\right]_{\mathrm{MOVER}}-$ $\left[\partial^{2} \Delta \mathrm{W} / \partial \mathrm{M} \partial \mathrm{U}\right]_{\text {STAYER }}$. The evidence in the table supports the model's predictions. The relationship between labor-market tightness and the wage disadvantage facing women is greater in the sample of job-movers than in the sample of job-stayers. Among all Hispanics and Hispanic men the negative impact of the cycle is also more pronounced among job-movers; the opposite is true among Hispanic women, but none of these differences is statistically significant. Remembering from Table 1 that the wage disadvantage of African-Americans drops significantly when unemployment rises, the results here suggest that this is due to the behavior of wage changes among job-movers: Among African-Americans generally, and both men and women, the wage disadvantage becomes smaller among job-movers as unemployment rises, but varies insignificantly statistically among job-stayers.

Not all the differences between job-movers and job-stayers are statistically significant; but except for Hispanic females the mover-stayer differences demonstrate that the cyclicality that we observed in the cross section (rising wage disadvantages with unemployment among women and Hispanics, falling among African-Americans) occurs especially through the wage changes experienced by job-movers. Remembering that our method of distinguishing job-movers and stayers necessarily blurs the distinction between them, these results seem fairly convincing. They suggest that it is through wage-setting as new implicit contracts are entered into that the market effects of discrimination 
become felt. Short-run increases in unemployment have less effect on wage differentials within jobs.

\section{Conclusion and Implications}

We have documented the existence of a relationship between discriminatory wage differentials and labor market tightness, as measured by either state unemployment rates or industry-based measures of shifts in labor demand. The evidence that a tighter labor market leads to a smaller discriminatory wage gap is strongest and most robust when comparing male and female wages, but the wage disadvantage facing Hispanics also seems to increase with unemployment. We find some evidence of a negative relationship between unemployment and the African-American-white wage gap.

We stress that our findings reflect only changes in pure wage discrimination, as we have abstracted from changes in composition. They say nothing about the differential incidence of job loss by gender, ethnicity or race as unemployment rises. However, the relationships that we uncover do not seem to be due to changes in the characteristics, either observable or unobservable, of employed workers that are associated with changes in unemployment rates.

We develop a search-theoretic model of wage discrimination driven by employer preferences to explore possible causes for these findings. In the model, the cost to the employer of discriminating rises with the tightness of the labor market, which lowers the

proportion of discriminators in the market; but recession leads to disproportionately greater exit by discriminating firms, so that the net effect on the amount of discrimination in the labor market and the tightness of the labor market is ambiguous. 
In the search model, changes in discriminatory wage differences must come through the wage changes experienced by workers who change jobs, as it includes no mechanism through which employers change the wages paid to continuing employees. We do find that the relationship between changes in the unemployment rate and changes in discriminatory wage differentials is stronger in samples of workers who did change jobs than in samples of job-stayers. "Discriminatory" wage disadvantages, rising with unemployment among women and Hispanics, falling among African-Americans, are observed disproportionally in the wage changes experienced by job-movers. The next step in re-opening this long-neglected area of study might be to use more detailed sets of data to infer the differential roles of the mechanisms indicated in our model that generate cyclical changes in pure wage discrimination and infer why the net effects differ among the groups we have studied. 


\section{REFERENCES}

Altonji, Joseph, and Rebecca Blank, "Race and Gender in the Labor Market," in O. Ashenfelter and D. Card, Handbook of Labor Economics, Volume 3C Amsterdam: Elsevier, 1999.

Ashenfelter, Orley, "Changes in Labor Market Discrimination Over Time," Journal of Human Resources, 5 (Fall 1970): 403-30.

Becker, Gary. The Economics of Discrimination. Chicago: University of Chicago Press, 1957.

Biddle, Jeff, and Daniel Hamermesh, "Beauty, Productivity and Discrimination: Lawyers' Looks and Lucre," Journal of Labor Economics , 16 (Jan. 1998): 172201.

Black, Dan, "Discrimination in an Equilibrium Search Model," Journal of $L$ abor Economics, 13 (April 1995): 309-33.

Blau, Francine, and Lawrence Kahn, "The U.S. Gender Pay Gap in the 1990s: Slowing Convergence," Industrial and Labor Relations Review, 60 (July 2006): 45-66.

Cain, Glen, "The Economic Analysis of Labor Market Discrimination: A Survey," in O. Ashenfelter and P.R.G. Layard, Handbook of Labor Economics, Volume 2 . Amsterdam: North-Holland, 1986.

Freeman, Richard, "Changes in the Labor Market for Black Americans, 1948-72," Brookings Papers on Economic Activity, (1973): 67-131.

-------, "Longitudinal Analyses of the Effects of Trade Unions," Journal of Labor Economics, 2 (Jan. 1984): 1-26.

Hall, Robert, "Why Is the Unemployment Rate So High at Full Employment?" Brookings Papers on Economic Activity, (1970): 369-410.

Hamermesh, Daniel. Beauty Pays. Princeton, NJ: Princeton University Press, 2011.

Kuhn, Peter, and Kailing Shen, "Gender Discrimination in Job Ads: Theory and Evidence," Unpublished paper, University of California — Santa Barbara, 2010.

Marston, Stephen, "Two Views of the Geographic Distribution of Unemployment," Quarterly Journal of Economics, 100 (Feb. 1985): 57-79.

Mulligan, Casey, and Yona Rubinstein, "Selection, Investment and Women's Relative Wages over Time," Quarterly Journal of Economics , 123 (Aug. 2008): 10611110 . 
O'Neill, June, "The Trend in the Male-Female Wage Gap in the United States," Journal of Labor Economics, 3 (Jan. 1985): S91-116.

Reder, Melvin, "A Theory of Occupational Wage Differentials," American Economic Review, 45 (Dec. 1955): 833-52.

Rosén, Åsa, "Search, Bargaining and Employer Discrimination," Journal of L abor Economics, 21 (Oct. 2003): 807-29.

Rosen, Sherwin, "The Market for Lawyers," Journal of Law and Economics , 35 (Oct. 1992): 215-46.

Smith, Adam, The Wealth of Nations. 1776. 
Table 1. Coefficient Estimates Describing In(Usual Weekly Earnings), CPS-MORG, 19792009, All Workers*

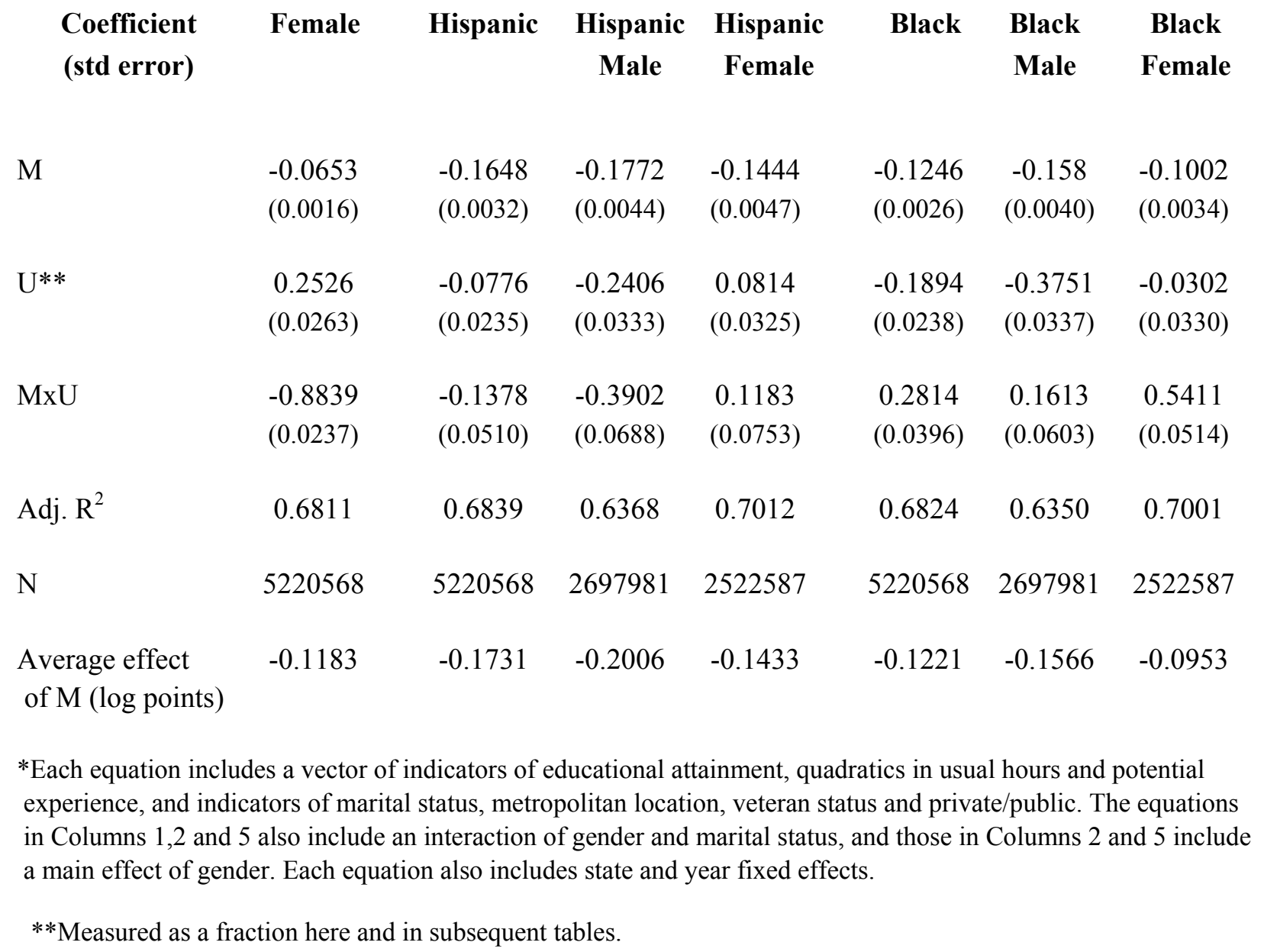


Table 2. Coefficient Estimates Describing In(Usual Weekly Earnings), CPS-MORG, 1979-2009, Workers with $<=5$ Years of Experience and $<16$ Years of Schooling*

\begin{tabular}{|c|c|c|c|c|c|c|c|}
\hline $\begin{array}{l}\text { Coefficient } \\
\text { (std error) }\end{array}$ & Female & Hispanic & $\begin{array}{c}\text { Hispanic } \\
\text { Male }\end{array}$ & $\begin{array}{l}\text { Hispanic } \\
\text { Female }\end{array}$ & Black & $\begin{array}{l}\text { Black } \\
\text { Male }\end{array}$ & $\begin{array}{c}\text { Black } \\
\text { Female }\end{array}$ \\
\hline M & $\begin{array}{r}-0.0528 \\
(0.0033)\end{array}$ & $\begin{array}{l}-0.0652 \\
(0.0068)\end{array}$ & $\begin{array}{l}-0.0682 \\
(0.0095)\end{array}$ & $\begin{array}{l}-0.0608 \\
(0.0097)\end{array}$ & $\begin{array}{c}-0.0551 \\
(0.0607)\end{array}$ & $\begin{array}{l}-0.0610 \\
(0.0089)\end{array}$ & $\begin{array}{r}-0.0450 \\
(0.0082)\end{array}$ \\
\hline $\mathrm{U}$ & $\begin{array}{l}-0.8412 \\
(0.0538)\end{array}$ & $\begin{array}{l}-1.0001 \\
(0.0481)\end{array}$ & $\begin{array}{l}-1.1176 \\
(0.0688)\end{array}$ & $\begin{array}{l}-0.7974 \\
(0.0668)\end{array}$ & $\begin{array}{l}-1.0603 \\
(0.0486)\end{array}$ & $\begin{array}{l}-1.2371 \\
(0.0693)\end{array}$ & $\begin{array}{c}-0.859 \\
(0.0674)\end{array}$ \\
\hline $\mathrm{MxU}$ & $\begin{array}{l}-0.4274 \\
(0.0493)\end{array}$ & $\begin{array}{c}0.0387 \\
(0.1064)\end{array}$ & $\begin{array}{l}-0.0975 \\
(0.1479)\end{array}$ & $\begin{array}{c}0.1855 \\
(0.1516)\end{array}$ & $\begin{array}{c}0.0304 \\
(0.0912)\end{array}$ & $\begin{array}{l}-0.2161 \\
(0.1345)\end{array}$ & $\begin{array}{c}0.2879 \\
(0.1230)\end{array}$ \\
\hline Adj. $\mathrm{R}^{2}$ & 0.7720 & 0.7724 & 0.7633 & 0.7763 & 0.7724 & 0.7632 & 0.7762 \\
\hline $\mathrm{N}$ & 753727 & 753727 & 378624 & 375103 & 753727 & 378624 & 375103 \\
\hline
\end{tabular}

*Same variables as in Table 1. State and year fixed effects in each equation. 
Table 3. Coefficient Estimates Describing In(Usual Weekly Earnings), CPS-MORG, Subperiods 1980-1992, 1993-2009, All Workers*

\begin{tabular}{|c|c|c|c|c|c|c|c|}
\hline $\begin{array}{l}\text { Coefficient } \\
\text { (std error) }\end{array}$ & Female & Hispanic & $\begin{array}{c}\text { Hispanic } \\
\text { Male }\end{array}$ & $\begin{array}{c}\text { Hispanic } \\
\text { Female }\end{array}$ & Black & $\begin{array}{l}\text { Black } \\
\text { Male }\end{array}$ & $\begin{array}{c}\text { Black } \\
\text { Female }\end{array}$ \\
\hline \multicolumn{8}{|c|}{ 1980-1992 } \\
\hline & $\begin{array}{l}-0.0935 \\
(0.0024)\end{array}$ & $\begin{array}{l}-0.1581 \\
(0.0063)\end{array}$ & $\begin{array}{l}-0.1940 \\
(0.0085)\end{array}$ & $\begin{array}{l}-0.1123 \\
(0.0091)\end{array}$ & $\begin{array}{l}-0.1165 \\
(0.0038)\end{array}$ & $\begin{array}{l}-0.1474 \\
(0.0057)\end{array}$ & $\begin{array}{l}-0.0931 \\
(0.0049)\end{array}$ \\
\hline & $\begin{array}{c}1.3084 \\
(0.0255)\end{array}$ & $\begin{array}{c}1.0601 \\
(0.0304)\end{array}$ & $\begin{array}{c}0.9148 \\
(0.0290)\end{array}$ & $\begin{array}{c}1.2562 \\
(0.0280)\end{array}$ & $\begin{array}{c}1.0322 \\
(0.0208)\end{array}$ & $\begin{array}{c}0.8990 \\
(0.0294)\end{array}$ & $\begin{array}{c}1.2006 \\
(0.0288)\end{array}$ \\
\hline $\mathrm{MxU}$ & $\begin{array}{l}-0.5639 \\
(0.0302)\end{array}$ & $\begin{array}{l}-0.3261 \\
(0.0874)\end{array}$ & $\begin{array}{l}-0.4059 \\
(0.1181)\end{array}$ & $\begin{array}{l}-0.2323 \\
(0.1271)\end{array}$ & $\begin{array}{c}0.0945 \\
(0.0502)\end{array}$ & $\begin{array}{l}-0.0930 \\
(0.0757)\end{array}$ & $\begin{array}{c}0.3744 \\
(0.0653)\end{array}$ \\
\hline Adj. $R^{2}$ & 0.6864 & 0.6889 & 0.6278 & 0.7011 & 0.6879 & 0.6263 & 0.7005 \\
\hline & 2514889 & 2514889 & 1331140 & 1183749 & 2514889 & 1331140 & 1183749 \\
\hline
\end{tabular}

1993-2009

$\begin{array}{llllllll}\mathrm{M} & -0.1391 & -0.1211 & -0.1406 & -0.0999 & -0.1108 & -0.1571 & -0.0755 \\ & (0.0026) & (0.0040) & (0.0054) & (0.0059) & (0.0011) & (0.0067) & (0.0054) \\ & & & & & & & \\ & & & & & & & \\ & -0.0628 & -0.3563 & -0.4569 & -0.2531 & -0.4472 & -0.5651 & -0.3185 \\ & (0.0351) & (0.0276) & (0.0398) & (0.0381) & (0.0273) & (0.0386) & (0.0385)\end{array}$

$\begin{array}{llllllll}\mathrm{MxU} & 0.4325 & -0.4624 & -0.5050 & -0.3575 & 0.1949 & 0.1406 & 0.1831\end{array}$

$\begin{array}{lllllll}(0.0452) & (0.0690) & (0.0938) & (0.1013) & (0.0764) & (0.1212) & (0.0964)\end{array}$

$\begin{array}{llllllll}\text { Adj. } \mathrm{R}^{2} & 0.6189 & 0.6216 & 0.5833 & 0.6263 & 0.6204 & 0.5823 & 0.6253\end{array}$

$\begin{array}{llllllll}\mathrm{N} & 2705679 & 2705679 & 1366841 & 1338838 & 2705679 & 1366841 & 1338838\end{array}$

*Same variables as in Table 1. State and year fixed effects in each equation. 
Table 4. Coefficient Estimates Describing $\Delta \ln$ (Usual Weekly Earnings), CPS-MORG, 19802009 and Sub-periods 1980-1992, 1993-2009, All Workers, Based on Longitudinal Data*

\begin{tabular}{|c|c|c|c|c|c|c|c|}
\hline $\begin{array}{l}\text { Coefficient } \\
\text { (std error) }\end{array}$ & Female & Hispanic & $\begin{array}{c}\text { Hispanic } \\
\text { Male }\end{array}$ & $\begin{array}{l}\text { Hispanic } \\
\text { Female }\end{array}$ & Black & $\begin{array}{l}\text { Black } \\
\text { Male }\end{array}$ & $\begin{array}{c}\text { Black } \\
\text { Female }\end{array}$ \\
\hline \multicolumn{8}{|c|}{ 1980-2009 } \\
\hline $\mathrm{U}$ & $\begin{array}{c}0.2208 \\
(0.0558)\end{array}$ & $\begin{array}{c}0.0840 \\
(0.0417)\end{array}$ & $\begin{array}{c}0.1251 \\
(0.0584)\end{array}$ & $\begin{array}{c}0.0514 \\
(0.0594)\end{array}$ & $\begin{array}{c}0.0270 \\
(0.0420)\end{array}$ & $\begin{array}{c}0.0645 \\
(0.0582)\end{array}$ & $\begin{array}{l}-0.0214 \\
(0.0604)\end{array}$ \\
\hline $\mathrm{MxU}$ & $\begin{array}{l}-0.4044 \\
(0.0799)\end{array}$ & $\begin{array}{l}-0.5567 \\
(0.1449)\end{array}$ & $\begin{array}{l}-0.6829 \\
(0.1948)\end{array}$ & $\begin{array}{l}-0.4979 \\
(0.2153)\end{array}$ & $\begin{array}{c}0.0370 \\
(0.1375)\end{array}$ & $\begin{array}{l}-0.1307 \\
(0.2059)\end{array}$ & $\begin{array}{c}0.2615 \\
(0.1854)\end{array}$ \\
\hline Adj. $R^{2}$ & 0.2989 & 0.2989 & 0.2460 & 0.3523 & 0.2989 & 0.2460 & 0.3523 \\
\hline $\mathrm{N}$ & 1824705 & 1824705 & 948100 & 876605 & 1824705 & 948100 & 876605 \\
\hline \multicolumn{8}{|c|}{ 1980-1992 } \\
\hline $\mathrm{U}$ & $\begin{array}{c}0.4196 \\
(0.0581)\end{array}$ & $\begin{array}{c}0.3469 \\
(0.0432)\end{array}$ & $\begin{array}{c}0.3381 \\
(0.0599)\end{array}$ & $\begin{array}{c}0.3504 \\
(0.0618)\end{array}$ & $\begin{array}{c}0.2934 \\
(0.0441)\end{array}$ & $\begin{array}{c}0.2808 \\
(0.0605)\end{array}$ & $\begin{array}{c}0.2937 \\
(0.0640)\end{array}$ \\
\hline $\mathrm{MxU}$ & $\begin{array}{l}-0.2593 \\
(0.0834)\end{array}$ & $\begin{array}{l}-0.8511 \\
(0.1979)\end{array}$ & $\begin{array}{l}-0.8824 \\
(0.2624)\end{array}$ & $\begin{array}{l}-0.8550 \\
(0.2990)\end{array}$ & $\begin{array}{c}0.1068 \\
(0.1473)\end{array}$ & $\begin{array}{c}0.1010 \\
(0.2210)\end{array}$ & $\begin{array}{c}0.1625 \\
(0.1951)\end{array}$ \\
\hline Adj. $\mathrm{R}^{2}$ & 0.3896 & 0.3896 & 0.3173 & 0.4651 & 0.3896 & 0.3173 & 0.4651 \\
\hline $\mathrm{N}$ & 839707 & 839707 & $\begin{array}{r}451279 \\
\mathbf{1 9 9 3 - 2 0 0 9}\end{array}$ & 388428 & 839707 & 451279 & 388428 \\
\hline $\mathrm{U}$ & $\begin{array}{c}0.4642 \\
(0.0590)\end{array}$ & $\begin{array}{c}0.4125 \\
(0.0437)\end{array}$ & $\begin{array}{c}0.4064 \\
(0.0606)\end{array}$ & $\begin{array}{c}0.4044 \\
(0.0627)\end{array}$ & $\begin{array}{c}0.3685 \\
(0.0448)\end{array}$ & $\begin{array}{c}0.3575 \\
(0.0614)\end{array}$ & $\begin{array}{c}0.3624 \\
(0.0650)\end{array}$ \\
\hline $\mathrm{MxU}$ & $\begin{array}{l}-0.1693 \\
(0.0849)\end{array}$ & $\begin{array}{l}-0.4925 \\
(0.2070)\end{array}$ & $\begin{array}{l}-0.4810 \\
(0.2742)\end{array}$ & $\begin{array}{l}-0.5190 \\
(0.3132)\end{array}$ & $\begin{array}{c}0.2062 \\
(0.1495)\end{array}$ & $\begin{array}{c}0.2699 \\
(0.2238)\end{array}$ & $\begin{array}{c}0.1778 \\
(0.1982)\end{array}$ \\
\hline Adj. $R^{2}$ & 0.3898 & 0.3898 & 0.3163 & 0.4671 & 0.3898 & 0.3163 & 0.4671 \\
\hline $\mathrm{N}$ & 767463 & 767463 & 414055 & 353408 & 767463 & 414055 & 353408 \\
\hline
\end{tabular}

*Also includes potential experience and current and past year's usual weekly hours, and year fixed effects. 
Table 5. CPS MORG 1979-2009, All Workers, Accounting for Industry Cyclicality (Trimmed Estimates)*

\begin{tabular}{|c|c|c|c|c|c|c|c|}
\hline $\begin{array}{l}\text { Coefficient } \\
\text { (std error) }\end{array}$ & Female & Hispanic & $\begin{array}{c}\text { Hispanic } \\
\text { Male }\end{array}$ & $\begin{array}{c}\text { Hispanic } \\
\text { Female }\end{array}$ & Black & $\begin{array}{l}\text { Black } \\
\text { Male }\end{array}$ & $\begin{array}{c}\text { Black } \\
\text { Female }\end{array}$ \\
\hline M & $\begin{array}{l}-0.0681 \\
(0.0017)\end{array}$ & $\begin{array}{l}-0.1768 \\
(0.0033)\end{array}$ & $\begin{array}{l}-0.1893 \\
(0.0044)\end{array}$ & $\begin{array}{l}-0.1550 \\
(0.0048)\end{array}$ & $\begin{array}{l}-0.1239 \\
(0.0027)\end{array}$ & $\begin{array}{l}-0.1597 \\
(0.0040)\end{array}$ & $\begin{array}{l}-0.0970 \\
(0.0035)\end{array}$ \\
\hline $\mathrm{U}$ & $\begin{array}{c}0.2941 \\
(0.0259)\end{array}$ & $\begin{array}{l}-0.0070 \\
(0.0232)\end{array}$ & $\begin{array}{l}-0.1769 \\
(0.0325)\end{array}$ & $\begin{array}{c}0.1387 \\
(0.0328)\end{array}$ & $\begin{array}{l}-0.1067 \\
(0.0235)\end{array}$ & $\begin{array}{l}-0.2957 \\
(0.0329)\end{array}$ & $\begin{array}{c}0.0373 \\
(0.0333)\end{array}$ \\
\hline $\mathrm{MxU}$ & $\begin{array}{l}-0.8036 \\
(0.0236)\end{array}$ & $\begin{array}{c}0.0264 \\
(0.0513)\end{array}$ & $\begin{array}{l}-0.2140 \\
(0.0691)\end{array}$ & $\begin{array}{c}0.2362 \\
(0.0760)\end{array}$ & $\begin{array}{c}0.2904 \\
(0.0400)\end{array}$ & $\begin{array}{c}0.2009 \\
(0.0601)\end{array}$ & $\begin{array}{c}0.5069 \\
(0.0520)\end{array}$ \\
\hline$\Delta \mathrm{H}$ & $\begin{array}{c}0.0877 \\
(0.0112)\end{array}$ & $\begin{array}{r}.0671 \\
(0.0091)\end{array}$ & $\begin{array}{c}0.0415 \\
(0.0118)\end{array}$ & $\begin{array}{c}0.0751 \\
(0.0142)\end{array}$ & $\begin{array}{c}0.1261 \\
(0.0090)\end{array}$ & $\begin{array}{c}0.1005 \\
(0.0119)\end{array}$ & $\begin{array}{c}0.1390 \\
(0.0147)\end{array}$ \\
\hline$\Delta \mathrm{H}^{*} \mathrm{U}$ & $\begin{array}{l}-2.421 \\
(0.149)\end{array}$ & $\begin{array}{l}-2.112 \\
(0.120)\end{array}$ & $\begin{array}{l}-2.494 \\
(0.154)\end{array}$ & $\begin{array}{l}-0.880 \\
(0.190)\end{array}$ & $\begin{array}{c}-2.548 \\
(0.123)\end{array}$ & $\begin{array}{l}-2.993 \\
(0.157)\end{array}$ & $\begin{array}{l}-1.250 \\
(0.097)\end{array}$ \\
\hline$\Delta \mathrm{H}^{*} \mathrm{M}$ & $\begin{array}{c}0.0223 \\
(0.0167)\end{array}$ & $\begin{array}{c}0.4455 \\
(0.0355)\end{array}$ & $\begin{array}{c}0.5434 \\
(0.0454)\end{array}$ & $\begin{array}{c}0.3760 \\
(0.0563)\end{array}$ & $\begin{array}{l}-0.0943 \\
(0.0284)\end{array}$ & $\begin{array}{l}-0.0944 \\
(0.0398)\end{array}$ & $\begin{array}{l}-0.1197 \\
(0.0405)\end{array}$ \\
\hline$\Delta \mathrm{H}^{*} \mathrm{M}^{*} \mathrm{U}$ & $\begin{array}{c}0.751 \\
(0.229)\end{array}$ & $\begin{array}{r}-3.684 \\
(0.516)\end{array}$ & $\begin{array}{r}-5.708 \\
(0.652)\end{array}$ & $\begin{array}{l}-2.276 \\
(0.823)\end{array}$ & $\begin{array}{c}1.139 \\
(0.382)\end{array}$ & $\begin{array}{c}1.141 \\
(0.525)\end{array}$ & $\begin{array}{c}0.750 \\
(0.550)\end{array}$ \\
\hline Adj. $\mathrm{R}^{2}$ & 0.6816 & 0.6845 & 0.6418 & 0.6968 & 0.6829 & 0.6398 & 0.6956 \\
\hline & 5044318 & 5044318 & 2599255 & 2445063 & 5044318 & 2599255 & 2445063 \\
\hline$\partial^{2} \mathrm{~W} / \partial \mathrm{M} \partial \Delta \mathrm{H}$ & 0.0674 & 0.2243 & 0.2007 & 0.2394 & -0.0259 & -0.0259 & -0.0747 \\
\hline
\end{tabular}

*Includes state and year fixed effects, and the same variables as in Table 1. Trimmed to exclude observations with an absolute annual change in industry employment $>50$ percent. 
Table 6. Estimates of the Effect of a One-Standard-Deviation Increase in Beauty on Male Attorneys' In(Earnings), Graduates 1972-77 and 1982-87*

\begin{tabular}{lcc} 
Cohort & \multicolumn{2}{c}{ Earnings Effect } \\
& Year 1 & Year 5 \\
& & \\
1972-77 Graduates & 0.0167 & 0.0431 \\
$(\mathrm{~N}=778)$ & $(0.0099)$ & $(0.0114)$ \\
& & \\
& & \\
1982-87 Graduates & 0.0053 & 0.0068 \\
$(\mathrm{~N}=789)$ & $(0) .0116)$ & $(0.0104)$
\end{tabular}

*Based on Biddle and Hamermesh (1998, Table 3). The estimates are adjusted for a wide variety of control variables. 
Table 7. Coefficient Estimates Describing $\Delta \ln ($ Usual Weekly Earnings), CPS-MORG, 19802009, Distinguishing Job-Movers from Job-Stayers*

$\begin{array}{lccccccc}\begin{array}{l}\partial^{2} \Delta \mathrm{W} / \partial \mathbf{M} \partial \mathbf{U} \\ \text { (std error) }\end{array} & \text { Female } & \text { Hispanic } & \begin{array}{c}\text { Hispanic } \\ \text { Male }\end{array} & \begin{array}{c}\text { Hispanic } \\ \text { Female }\end{array} & \text { Black } & \begin{array}{c}\text { Black } \\ \text { Male }\end{array} & \begin{array}{c}\text { Black } \\ \text { Female }\end{array} \\ \text { Movers } & & & & & & & \\ & -0.7436 & -0.6266 & -0.8729 & -0.0474 & 0.2560 & 0.0163 & 0.6588 \\ & (0.1453) & (0.2419) & (0.3272) & (0.3510) & (0.2382) & (0.3543) & (0.3200) \\ \text { Stayers } & & & & & & & \\ & -0.1206 & -0.4782 & -0.5484 & -0.4192 & -0.1145 & -0.2753 & 0.0296 \\ & (0.0888) & (0.1699) & (0.2229) & (0.2632) & (0.1592) & (0.2291) & (0.2205) \\ \text { Movers -Stayers } & -0.6230 & -0.1484 & -0.3245 & 0.3718 & 0.3704 & 0.2916 & 0.6292 \\ & (0.1703) & (0.2956) & (0.3959) & (0.4387) & (0.2865) & (0.4219) & (0.3886)\end{array}$

*Same variables as in Table 4 . 


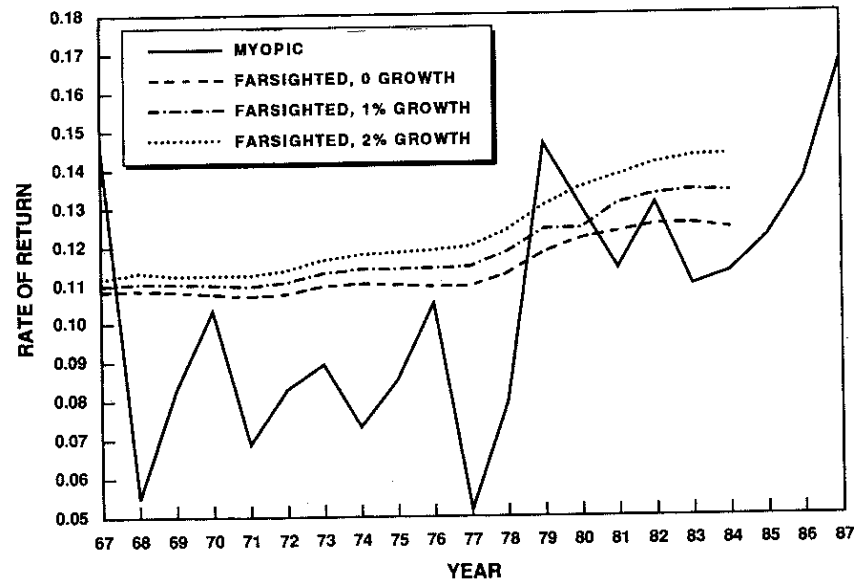

Figure 1. Rate of Return on Law School, 1967-87, from Rosen (1992, Figure 6). 


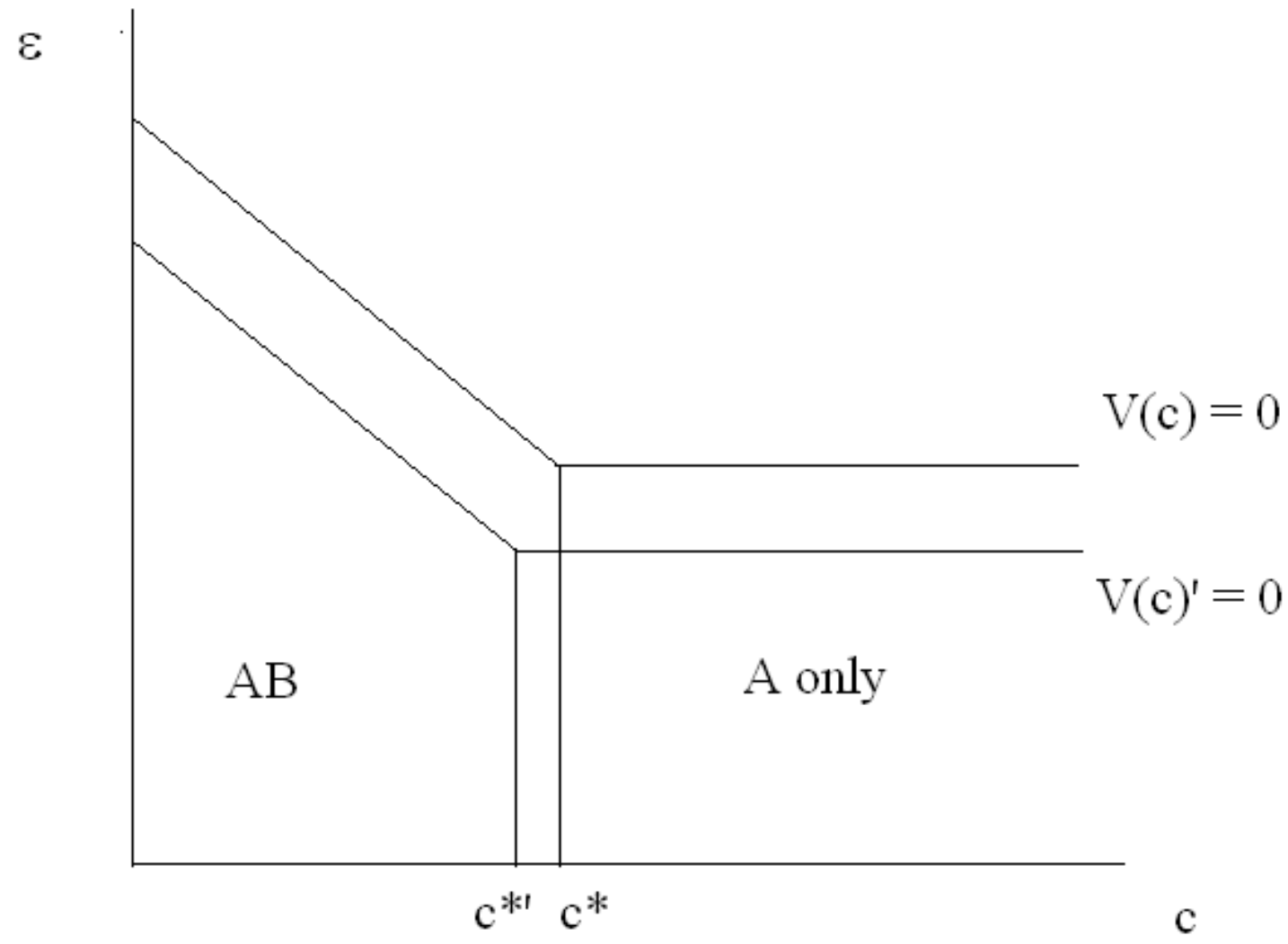

Figure 2. Job Openings and Employers' Tastes for Discrimination 